\title{
KESALAHAN BERBAHASA PADA KARANGAN EKSPOSISI SISWA SEKOLAH MENENGAH ATAS: BENTUK, FAKTOR PENYEBAB, DAN UPAYA MENGATASI
}

\author{
Utari Kismawati, Sumarwati, Nugraheni Eko Wardhani \\ Universitas Sebelas Maret \\ Surel: utarikismawati30@gmail.com
}

\begin{abstract}
Abstrak: Penelitian ini menggunakan metode penelitian kualitatif dengan pendekatan content analysis. Partisipan penelitian ini adalah 130 karangan siswa kelas X IIS Sekolah Menengah Atas Negeri 6 Surakarta. Teknik pengambilan sampel yang digunakan adalah purposive sampling. Teknik pengumpulan data yang digunakan adalah analisis dokumen (content analysis) dan wawancara mendalam (in-dept interview-ing). Analisis data dalam penelitian ini menggunakan model analisis interaktif. Simpulan penelitian ini adalah sebagai berikut. Pertama, kesalahan bahasa dalam karangan eksposisi siswa dibagi menjadi tiga kesalahan: kesalahan kalimat, kesalahan diksi, dan kesalahan ejaan. Kedua, kesalahan ejaan adalah kesalahan yang paling banyak ditemukan pada karangan eksposisi siswa dengan frekuensi tertinggi pada penggunaan tanda koma. Ketiga, faktor penyebab kesalahan bahasa pada karangan eksposisi siswa, antara lain: minimnya pengetahuan siswa tentang kaidah penulisan, minimnya motivasi membaca siswa, kecenderungan siswa menomorduakan tata tulis dibandingkan ide karangan, kebisaan siswa untuk tidak merevisi karangan sebelum dikumpulkan, suasana kelas yang tidak kondusif, dan tuntutan kompetensi menulis yang sebatas benar secara struktur teks. Keempat, upaya yang dilakukan untuk meminimalisasi kesalahan berbahasa, antara lain guru segera mengklarifikasi kesalahan berbahasa siswa yang ditemukan dalam pembelajaran, antar-siswa melakukan aktivitas saling-baca karangan sebelum dikumpulkan kepada guru, dan penambahan alokasi waktu untuk aktivitas menulis di kelas.
\end{abstract}

Kata kunci: analisis, kesalahan berbahasa, karangan eksposisi

\section{LANGUAGE MISTAKES ON THE EXPOSITION OF SENIOR HIGH SCHOOL STUDENTS: FORMS, CAUSES FACTORS, AND OVERCOME EFFORTS}

\begin{abstract}
The research population was all tenth grade Social students of Sekolah Menengah Atas Negeri 6 Surakarta. The research method used was qualitative method using descriptive-qualitative approach. The participants of the research were one hundred thirty (130) Social students' works. The sampling technique used was purposive sampling. Data collection techniques were content analysis and in-depth interviewing. Data analyzing used was interactive analysis model. The followings are the conclusions of the research. First, three types of language errors in students' exposition text are sentence error, diction error, and spelling error. Second, the most detected type of error is spelling error in which the use of comma has the highest percentage. Third, the casual factors of language error were as follow: the students know less about writing principles; the students have less motivation to read; the students tend to emphasize the idea rather than writing principle; the students tend to be lazy to do editing before submitting their works; the class condition is not supportive; and the students are demanded to write structurally correct. Fourth, some efforts done to minimize language error: teachers give clarification immediately when they notice language error; cross-reading among students before submitting their works; and more writing activities in class.
\end{abstract}

Keywords: analysis, language error, exposition text

BASASTRA Jurnal Bahasa, Sastra, dan Pengajarannya

Volume 6 Nomor 2, Oktober 2018, ISSN 2302-6405 


\section{PENDAHULUAN}

Menulis adalah berkomunikasi. Komunikasi ini terjalin antara penulis dan pembaca. Dalam berkomunikasi, tentu ada pesan yang dikirim penulis dan dipahami pembaca. Agar pesan penulis benar-benar sampai kepada pembaca, tulisan disusun dengan mendaftar gagasan, mengurutkan, dan menyusunnya menjadi sebuah wacana. Gagasan-gagasan ini diurutkan agar lebih sistematis dan mudah dipahami pembaca. Gagasan ini dituangkan menjadi kalimatkalimat yang tersusun rapi dalam paragaraf hingga menjadi kesatuan wacana yang utuh. Dalam berkomunikasi dengan pembaca, penulis harus mempu membuat paragraf yang padu sehingga terasa enak dibaca dan mudah dipahami karena kalimat-kalimatnya memiliki satu kesatuan yang utuh dan padu (Dalman, 2015: 90.93). Untuk memiliki berbagai kemampuan itu, penulis perlu mempelajari diksi (pilihan kata), tatabahasa, dan retorika (Gie, 1995: 18).

Menulis merupakan salah satu dari empat keterampilan berbahasa dalam pembelajaran bahasa Indonesia. Menulis dalam pembelajaran bahasa Indonesia kurikulum 2013 biasanya dimunculkan pada kegiatan mengomunikasikan (mendalami materi yang dipelajari dalam bentuk tertulis) dalam metode saintifik. Salah satu produk aktivitas menulis dalam pembelajaran Bahasa Indonesia kelas X SMA adalah karangan eksposisi.

Karangan eksposisi adalah bentuk wacana yang menguraikan benda atau menyingkapkan buah pikiran, dan perasaan penulis dengan tujuan memperluas pandangan atau pengetahuan pembaca. Menurut Dalman (2015: 21-22), eksposisi adalah karangan yang memaparkan suatu gagasan atau suatu topik tertentu dengan tujuan semata-mata hanya untuk menambah wawasan si-pembacanya dan tidak untuk mempengaruhi si-pembacanya. Oleh karena itu, jenis karangan ini sama sekali tidak bermaksud mempengaruhi atau mengubah sikap dan pendapat orang lain atau pembacanya.

Menurut Marahimin (1999: 202-203), menulis wacana eksposisi berarti melatih siswa berpikir logis dan sistematis. Akan tetapi, berpikir logis dan sistematis hanya bisa dicapai siswa jika mereka diminta menuliskan wacana eksposisi, bukan jika mereka hanya diajarkan apa eksposisi itu, apa ciri-cirinya, apa gunanya, dan segala halhal teoretis seperti itu. Oleh karena itu, menulis karangan eksposisi termasuk salah satu kompetensi yang harus dikuasai oleh siswa kelas X SMA dalam pembelajaran Bahasa Indonesia. Hal ini dapat ditemukan dalam silabus mata pelajaran Bahasa dan Sastra Indonesia (Wajib) Kurikulum 2013 SMA Negeri 6 Surakarta, yaitu pada kompetensi 3.2 membandingkan teks eksposisi baik lisan maupun tulisan 4.2 memproduksi teks eksposisi yang koheren sesuai dengan karakteristik teks yang akan dibuat baik secara lisan maupun tulisan.

Aktivitas menulis siswa dalam proses pembelajaran tentu tidak sepenuhnya terlepas dari kesalahan berbahasa. Kesalahan-kesalahan yang biasa terjadi pada hasil tulisan siswa adalah kesalahan yang berhubungan dengan kemampuan pendukung. Menurut Morsey (1976), kemampuan pendukung tersebut meliputi: kesalahan pikiran, organisasi, pemakaian kata-kata, dan struktur kalimat yang digunakan penulis dan tidak sesuai dengan kaidah Bahasa Indonesia. Kesalahankesalahan seperti itu dapat disebut dengan istilah kesalahan berbahasa.

Dalam proses pembelajaran bahasa, analisis kesalahan berbahasa lazim dilakukan. Analisis kesalahan berbahasa, menurut Ellis dalam Tarigan dan Tarigan (1990: 68), adalah suatu prosedur kerja, yang biasa digunakan oleh peneliti dan guru bahasa, yang meliputi pengumpulan sampel, pengidentifikasian kesalahan yang terdapat 
dalam sampel, penjelasan kesalahan tersebut, pengklasifikasian kesalahan itu berdasarkan penyebabnya, serta pengevaluasian atau penilaian taraf keseriusan kesalahan itu.

Secara umum, kesalahan berbahasa yang dilakukan siswa, khususnya pada aspek menulis, merupakan hal yang wajar mengingat siswa masih dalam tahap belajar. Namun, apabila kesalahan tersebut tetap dibiarkan tanpa adanya upaya perbaikan, kondisi inilah yang akan menjadi penghambat peningkatan pengetahuan siswa terhadap sistem atau kaidah bahasa yang dipelajarinya. Oleh karena itu, latihan dan upaya perbaikan terus-menerus diperlukan selama proses pembelajaran.

Penelitian ini bertujuan untuk mendeskripsikan (1) jenis kesalahan berbahasa; (2) frekuensi kesalahan berbahasa yang paling banyak ditemukan;

(3) faktor penyebab terjadinya kesalahan berbahasa; dan (4) upaya yang dilakukan untuk meminimalkan kesalahan berbahasa pada karangan eksposisi siswa.

\section{METODE PENELITIAN Pendekatan Penelitian}

Penelitian ini dilaksanakan di Sekolah Menengah Atas Negeri 6 Surakarta. Penelitian ini menggunakan metode penelitian kualitatif dengan pendekatan content analysis. Menurut Krippendorff (2004:18), content analysis is a research technique for making replicable and valid inferences from texts (or other meaningful matter) to the contexts of their use. Analisis konten adalah sebuah teknik penelitian untuk membuat kesimpulan yang dapat diaplikasikan dan valid dari teks-teks (atau hal-hal bermakna lain) sampai pada konteks penggunaannya.

\section{Partisipan}

Partisipan penelitian ini adalah 130 karangan siswa kelas $\mathrm{X}$ IIS Sekolah Menengah Atas Negeri 6 Surakarta.

\section{Pengumpulan data}

Teknik pengambilan sampel yang digunakan adalah teknik purposive sampling. Purposive sampling dalam penelitian kualitatif, menurut Sutopo, sering disebut sebagai "internal sampling" karena sama sekali bukan dimaksudkan untuk mengusahakan generalisasi pada populasi, tetapi untuk memperoleh kedalaman studi di dalam suatu konteks tertentu. Sampling ini bukan mewakili populasinya melainkan mewakili informasinya. Teknik pengumpulan data dilakukan dengan teknik analisis dokumen (content analysis) untuk sumber data karangan eksposisi siswa kelas $X$ IIS SMA Negeri 6 Surakarta dan wawancara mendalam (in-dept interviewing) untuk sumber data guru pengampu mata pelajaran Bahasa Indonesia dan siswa kelas $X$ IIS SMA Negeri 6 Surakarta. Teknik uji validitas data yang digunakan adalah teknik triangulasi data dan review informan.

\section{Analisis data}

Teknik analisis data penelitian ini menggunakan teknik analisis kuantitatif dan kualitatif deskriptif. Analisis data kuantitatif digunakan untuk menghitung frekuensi, ratarata, dan persentase kesalahan berbahasa karangan eksposisi. Analisis kualitatif deskriptif digunakan untuk menyajikan data hasil wawancara tentang faktor penyebab kesalahan berbahasa dan upaya yang dilakukan untuk meminimalisasi kesalahan berbahasa secara verbal.

\section{Prosedur Penelitian}

Adapun prosedur yang dilakukan peneliti dalam penelitian ini meliputi (1) mengidentifikasi kesalahan berbahasa pada karangan eksposisi, (2) membuat kartu data kesalahan berbahasa kalimat, diksi, dan ejaan, (3) mengklasifikasi kartu data kesalahan berbahasa yang telah dibuat, (4) menghitung kesalahan setiap aspek kesalahan berbahasa, (5) membuat 
rekapitulasi data dalam tabel, (6) melakukan wawancara untuk mengidentifikasi faktor penyebab kesalahan berbahasa, dan (7) melakukan wawancara untuk mengidentifikasi upaya yang dilakukan untuk meminimalisasi kesalahan berbahasa.

\section{HASIL DAN PEMBAHASAN}

Penelitian tentang menulis karangan pada hakikatnya memiliki banyak aspek yang bisa diteliti, seperti kesalahan berbahasa, analisis wacana, dan sebagainya. Akan tetapi, penelitian ini hanya menganalisis tentang kesalahan pemakaian Bahasa Indonesia. Aspek kesalahan berbahasa yang dianalisis meliputi kesalahan dalam bidang kalimat, diksi, dan ejaan.

Jumlah sampel sebanyak 130 karangan yang diambil dengan teknik purposive sampling. Karangan tersebut diambil dari tugas menulis mata pelajaran Bahasa Indonesia kelas X semester gasal pada materi teks eksposisi. Karangan tersebut merupakan karangan eksposisi siswa kelas X IIS 1, 2, 3, dan 4 SMA Negeri 6 Surakarta.

\section{Bentuk dan Jenis Kesalahan Berbahasa}

(1) Dengan Teknologi ini dapat memudahkan manusia melakukan aktivitasnya yg bersifat positif. (B.29 Pr.1 K1.6)

(2) Berbeda dengan zaman sekarang yang dapat mengirim pesan dengan amat sangat mudah. (A.26 Pr.3 K1.7)

Kesalahan berbahasa pada kalimat

(1) adalah tidak ditemukannya unsur subjek pada struktur kalimatnya. Agar unsur subjek muncul, kata dengan pada kalimat (1) harus dihilangkan dari struktur kalimat tersebut. Oleh karena itu, kalimat (1) sebagai kalimat yang padu sebagai berikut.

(3) Teknologi ini dapat
memudahkan manusia
melakukan aktivitasnya yang
bersifat positif.

Kesalahan berbahasa pada kalimat (2) adalah digunakannya dua kata yang semakna dalam kalimat tersebut, yaitu kata amat dan sangat. Kedua kata tersebut bermakna terlalu, amat bermakna terlalu; sangat, sangat bermakna terlebih (halnya, keadaannya); amat; terlalu; sungguhsungguh. Penggunaan dua kata yang semakna dalam satu kalimat menyebabkan terbentuknya kalimat yang tidak hemat. Agar kalimat (2) menjadi kalimat yang hemat, salah satu kata semakna pada kalimat tersebut harus dihilangkan. Oleh karena itu, kalimat (2) sebagai kalimat yang hemat sebagai berikut.

(4) Berbeda dengan zaman dahulu, sekarang orang-orang dapat mengirim pesan dengan amat mudah.

Atau

Berbeda dengan zaman dahulu, sekarang orang-orang dapat mengirim pesan dengan sangat mudah.

\section{Kesalahan Pemilihan Kata}

(5) Apabila sudah mempunyainya pasti isinya cuma bisa buat sms, telfon dll. (B.29 Pr.3 Kl.3)

(6) Karena HP itu sangat canggih, sekali tekan OK bisa mengirim pesan singkat ke beberapa nomer kontak. (A.20 Pr.2 Kl.3)

(7) bedug digunakan untuk mengumandangkan adzan. (A.19 Pr.1 K1.5)

(8) Kita harus membeli perangko yang harganya mahal, mengantarkan ke pos untuk diantar ke tempat yg akan dituju. (A.26 Pr.3 K1.5)

Kesalahan berbahasa pada kalimat (5) hingga (8) adalah terdapat penggunaan kata tidak baku dalam kalimat tersebut. Kesalahan ditemukan pada pemilihan kata telfon, nomer, adzan, dan perangko. Berdasarkan Kamus Besar Bahasa Indonesia, keempat kata tersebut seharusnya dalam 
versi baku adalah telepon, nomor, azan, dan prangko. Adapun penulisan keempat kata tersebut pada kalimat (5) hingga (8) sebagai berikut.

(9) Apabila sudah mempunyainya pasti isinya cuma bisa buat sms, telepon dll. (B.29 Pr.3 Kl.3)

(10) Karena HP itu sangat canggih, sekali tekan OK bisa mengirim pesan singkat ke beberapa nomor kontak. (A.20 Pr.2 Kl.3)

(11) bedug digunakan untuk mengumandangkan azan. (A.19 Pr.1 $\mathrm{K} 1.5$ )

(12) Kita harus membeli prangko yang harganya mahal, mengantarkan ke pos untuk diantar ke tempat yg akan dituju. (A.26 Pr.3 K1.5)

\section{Kesalahan Penggunaan Ejaan}

(13) Bahasa daerah, masing-masing daerah pasti punya bahasa masingmasing di antaranya bahasa jawa, bahasa sunda, bahasa madura, bahasa minangkabau dll. (B.21 Pr.3 K1.1)

(14) Berjalannya era globalisasi terjadinya pertukaran budaya seperti di SMP Muh 7 SKA. (B.30 Pr.6 Kl.1)

(15) Jika ini tetap dipertahankan kebudayaan indonesia sedikit demi sedikit akan di akui oleh negara lain karena orang indonesia tidak berusaha untuk melestarikan dan mereka lebih memilih meninggalkan budaya. (A.1 Pr.4 Kl.2)

(16) Kita harus mengambil hikmah tentang perkembangan Teknologi ini karena teknologi ini berguna sampai kita tua asalkan kita gunakan sebaik2nya. (B.29 Pr.5 Kl.2)

(17) Maka dari itu jangan dibandingkan bahasa daerah sendiri, Karena budaya sendiri. itu lbih baik dari pada budaa barat (B.21 Pr.3 Kl.4)
(18) Misalnya seperti perangkat2 \& aplikasi yg belum ada pada masa lalu. (B.19 Pr.2 K1.3)

Pada kalimat (13), ditemukan kesalahan penulisan huruf kapital pada nama bahasa. Berdasarkan PUEBI Edisi Keempat halaman 8, huruf kapital dipakai sebagai huruf pertama nama bangsa, suku bangsa, dan bahasa. Kata jawa, sunda, madura, dan minangkabau termasuk nama bahasa. Seharusnya, huruf pertama setiap kata tersebut ditulis dengan huruf kapital. Adapun penulisan huruf kapital yang tepat pada kalimat (13) sebagai berikut.

(19) ... bahasa Jawa, bahasa Sunda, bahasa Madura, bahasa Minangkabau dll.

Kesalahan yang ditemukan pada kalimat (14) adalah kesalahan penggunaan tanda titik pada penulisan singkatan. Berdasarkan PUEBI Edisi Keempat halaman 27, singkatan yang terdiri atas tiga huruf atau lebih diikuti dengan tanda titik. Kata Muh pada kalimat (14) termasuk singkatan yang terdiri atas tiga huruf. Seharusnya, singkatan tersebut diikuti dengan tanda titik. Adapun penggunaan tanda titik pada kalimat (14) sebagai berikut.

(20) Berjalannya era globalisasi terjadinya pertukaran budaya seperti di SMP Muh. 7 SKA.

Kesalahan berbahasa pada kalimat (15) adalah tidak digunakannya tanda koma setelah anak kalimat yang mendahului induk kalimat. Berdasarkan PUEBI Edisi Keempat halaman 40, tanda koma dipakai untuk memisahkan anak kalimat yang mendahului induk kalimatnya. Pada kalimat (15), anak kalimat berada di depan induk kalimat. Seharusnya, tanda koma digunakan setelah penulisan anak kalimat tersebut sebagai pemisah dengan induk kalimat yang mengikutinya. Adapun penggunaan tanda koma yang tepat pada kalimat (15) sebagai berikut. 
(21) Jika ini tetap dipertahankan(,) kebudayaan indonesia sedikit demi sedikit akan di akui oleh negara lain karena orang indonesia tidak berusaha untuk melestarikan dan mereka lebih memilih meninggalkan budaya.

Kesalahan berbahasa pada kalimat (16) adalah tidak digunakannya tanda hubung pada unsur kata ulang. Berdasarkan PUEBI Edisi Keempat halaman 47, tanda hubung dipakai untuk menyambung unsur kata ulang. Pada kalimat (16), terdapat kata sebaik baiknya sebagai unsur kata ulang. Seharusnya, kata ulang tersebut dibubuhi tanda hubung di antaranya. Adapun penggunaan tanda hubung yang tepat pada kalimat (16) sebagai berikut.

(22) Kita harus mengambil hikmah tentang perkembangan Teknologi ini karena teknologi ini berguna sampai kita tua asalkan kita gunakan sebaik-baiknya.

Kesalahan berbahasa pada kalimat (17) adalah penulisan gabungan kata daripada secara terpisah. Kata daripada termasuk preposisi perbandingan, yaitu preposisi yang menyatakan perbandingan antara dua tindakan atau dua hal (Chaer, 2009: 115). Gabungan kata tersebut seharusnya ditulis serangkai. Adapun penulisan gabungan kata daripada yang tepat sebagai berikut.

(23) Maka dari itu jangan dibandingkan bahasa daerah sendiri, Karena budaya sendiri. itu lbih baik daripada budaya barat

Kesalahan berbahasa pada kalimat

(18) adalah ditemukan penggunaan singkatan pada kata ulang perangkat2. Berdasarkan PUEBI Edisi Keempat halaman 18, bentuk ulang ditulis dengan menggunakan tanda hubung (-) di antara unsur-unsurnya. Oleh karena itu, kata perangkat2 seharusnya ditulis lengkap dengan tanda hubung di antara unsurunsurnya sebagai berikut.

(24) Misalnya seperti perangkat()perangkat \& aplikasi yg belum ada pada masa lalu.

\section{Kesalahan Berbahasa yang Paling Banyak Ditemukan pada Karangan Eksposisi}

Perbandingan yang lebih jelas mengenai frekuensi kesalahan berbahasa pada karangan eksposisi siswa dapat dilihat pada diagram berikut.

Diagram 1. Frekuensi Kesalahan Berbahasa

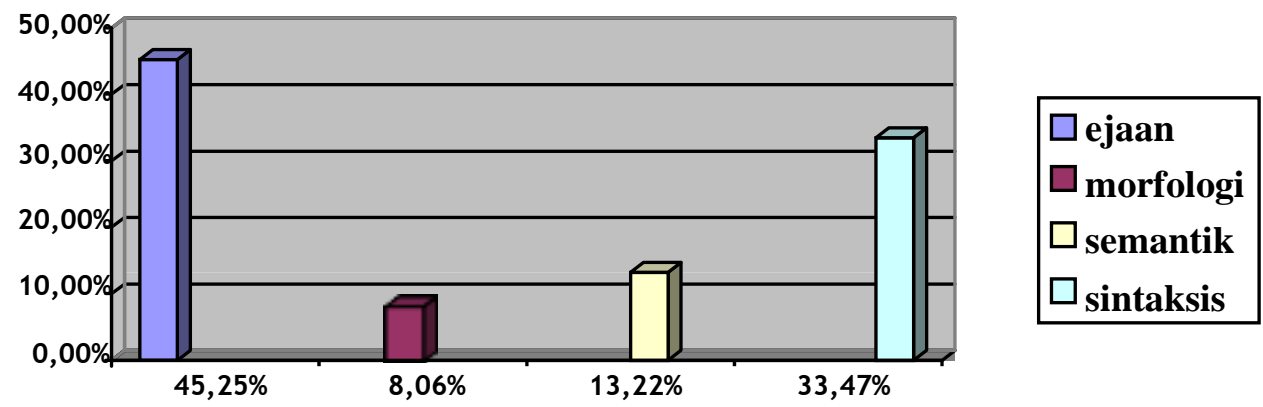

Kesalahan berbahasa yang paling ejaan sebanyak $45,25 \%$ dengan persentase banyak ditemukan dalam penelitian ini adalah kesalahan bidang ejaan. Kesalahan 
tertinggi pada penggunaan tanda koma (284 kalimat). Selanjutnya, kesalahan berbahasa bidang sintaksis sebayak 33,47 \% dengan persentase tertinggi pada penggunaan kalimat yang tidak padu (356 kalimat). Kesalahan bidang semantik sebanyak $13,22 \%$ dengan persentase tertinggi pada penggunaan kata yang tidak sesuai (145 kalimat). Terakhir, kesalahan berbahasa bidang morfologi sebanyak 8,066 \% dengan persentase tertinggi pada penulisan kata depan (64 kalimat).

\section{Faktor Penyebab Kesalahan Berbahasa pada Karangan Eksposisi}

Pertama, minimnya pengetahuan siswa tentang kaidah penulisan. Pengetahuan kebahasaan siswa yang minim memicu terjadinya kesalahan berbahasa yang bersifat sistematis, konsisten, dan menggambarkan kemampuan peserta didik pada tahap tertentu (yang biasanya belum sempurna). Dengan kata lain, kesalahan ini dapat menggambarkan bahwa peserta didik belum memahami benar bahasa yang dipelajarinya (Markhamah dan Sabardilah, 2011). Pengetahuan kebahasaan siswa yang minim, menurut Drs. Agus Setiyono, pengampu mata pelajaran Bahasa Indonesia, bermula dari intensitas pengetahuan yang diperoleh siswa tentang kebahasaan yang sedikit.

Kedua, minimnya motivasi membaca siswa. Terbentuknya budaya serba instan di zaman modern ini, menurut Sunarno, S.Pd., pengampu mata pelajaran Bahasa Indonesia, turut membuat siswa tidak ingin membaca di perpustakaan, tetapi mereka memilih jalan pintas dengan mengutip dari internet untuk mengerjakan tugas dari guru. Menurutnya, kegemaran membaca berpengaruh pada kemampuan siswa dalam mendapatkan ide. Siswa yang gemar membaca akan mudah mendapatkan ide sehingga dapat segera menuangkannya dalam bentuk tulisan, sedangkan siswa yang tidak gemar membaca akan menyita banyak waktu untuk memikirkan ide tulisannya sehingga banyak waktu yang habis untuk berpikir dibandingkan menulis. Selain perkembangan zaman, faktor kurangnya lingkungan yang membudayakan membaca bagi siswa turut berpengaruh pada motivasi membaca siswa.

Ketiga, kecenderungan siswa menomorduakan tata tulis dibandingkan ide karangan. Salah satu penyebab kesalahan berbahasa pada karangan eksposisi siswa adalah siswa menomorduakan tata tulis dibandingkan ide karangan. Kondisi ini turut didukung oleh alokasi waktu kegiatan menulis yang terbatas dan ketentuan guru tentang jumlah kata minimal dalam sebuah karangan yang harus dipenuhi siswa. Oleh karena itu, siswa lebih fokus pada ide yang akan dituliskan dan cenderung mengesampingkan kaidah penulisan yang baik dan benar. Hal ini senada dengan ungkapan Dani, siswa kelas $\mathrm{X}$, bahwa setelah berimajinasi tentang ide karangan, ia segera menuliskannya dalam bentuk tulisan untuk menghindari kehilangan ide yang telah didapatkan. Dampaknya, ia tidak memperhatikan kaidah penulisan yang baik dan benar. Selain itu, menurut Toni, jumlah kata minimal yang ditentukan guru dalam sebuah karangan membuatnya tidak leluasa mencari ide karangan dan menuliskannya. Hal ini membuat ia lebih fokus untuk segera mendapatkan ide agar dapat memenuhi ketentuan jumlah kata minimal tersebut mengingat waktu yang terbatas.

Keempat, kebiasaan siswa untuk tidak merevisi karangan sebelum dikumpulkan. Salah satu penyebab kesalahan berbahasa pada karangan eksposisi siswa adalah siswa tidak melakukan revisi pada karangannya sebelum dikumpulkan pada guru Bahasa Indonesia. Kondisi ini terjadi pada Dyota. Setelah selesai mengarang, ia langsung mengumpulkannya ke guru tanpa membaca atau menelitinya lebih dulu. Selain belum mengerti arti penting revisi karangan, menurut Bapak Agus, siswa merasa bahwa orientasi yang dicapai dalam kegiatan menulis adalah selesai dan langsung dikumpulkan kepada guru sebagai tugas bahasa Indonesia. 
Kelima, suasana kelas yang tidak kondusif. Suasana kelas yang tidak kondusif saat mengarang merupakan salah satu penyebab kesalahan berbahasa pada karangan eksposisi siswa. Menurut Ema, siswa kelas $\mathrm{X}$, saat aktivitas mengarang, kondisi kelas yang ditempatinya sangat ramai sehingga mengganggu konsentrasinya mengarang. Selain itu, menurut Bapak Sunarno, pembelajaran mengarang di siang hari turut mempengaruhi proses berpikir dan konsentrasi siswa. Aktivitas mengarang di kelas dilakukan setelah istirahat pertama atau menjelang siang hari. Konsentrasi dan proses berpikir siswa pada suasana tersebut turut mengalami penurunan.

Keenam, tuntutan kompetensi menulis yang sebatas pada struktur teks. Menurut Bapak Agus, kompetensi pembelajaran menulis yang dituntut dari siswa kelas $\mathrm{X}$ sebatas kesesuaian tulisan dengan struktur teks yang ditulis. Hal ini berbeda dengan kompetensi menulis kelas IX yang menekankan pada penguasaan tata tulis, yaitu pada kegiatan menyunting teks. Oleh karena itu, pembelajaran menulis kelas $\mathrm{X}$ difokuskan pada kesesuaian karangan dengan struktur teks, sedangkan unsur kebahasaan karangan dibahas jika ditemukan kesalahan kebahasaan selama proses pembelajaran.

\section{Upaya untuk Meminimalisasi Kesalahan Berbahasa pada Karangan Eksposisi}

Upaya yang dilakukan untuk meminimalisasi kesalahan berbahasa pada karangan eksposisi siswa, antara lain

Pertama, guru segera mengklarifikasi kesalahan berbahasa siswa yang ditemukan dalam pembelajaran. Bapak Sunarno menerapkan koreksi langsung pada karangan siswa, yaitu dengan cara menandai kesalahan berbahasa yang ditemukan dengan pulpen tinta merah dan menyertakan keterangan pembenarannya. Setelah dikoreksi guru, karangan biasanya dikembalikan kepada siswa. Selain itu, Bapak Agus menerapkan teknik mengoreksi silang karangan antarsiswa dan diskusi kelas sebagai upaya meminimalisasi kesalahan berbahasa yang ditemukan dalam karangan siswa. Diskusi kelas yang dilakukan biasanya melalui aktivitas presentasi dan menanggapi yang dibatasi hanya sekali tanggapan.

Kedua, antarsiswa melakukan aktivitas saling baca karangan sebelum dikumpulkan kepada guru. Dalam rangka menghindari subjektivitas penilaian, tahap revisi karangan eksposisi dilakukan secara silang antarsiswa. Dengan demikian, kesalahan berbahasa dapat diminimalkan karena revisi dilakukan oleh lebih dari satu siswa. Aktivitas revisi silang ini juga dilakukan oleh Dani. Sebagai upaya meminimalkan kesalahan berbahasa pada karangannya, Dani berdiskusi dengan teman sebangkunya tentang diksi yang tepat dan bertukar karangan dengan teman sebangku dalam rangka saling koreksi sebelum mengumpulkan karangan pada guru.

Ketiga, penambahan alokasi waktu untuk aktivitas menulis di kelas. Penambahan alokasi waktu untuk aktivitas menulis di kelas dirasa perlu. Penambahan alokasi waktu aktivitas menulis di kelas berarti pemberian akses yang lebih besar bagi siswa untuk menambah pengetahuan dan keterampilannya mengenai kaidah penulisan bahasa Indonesia yang baik dan benar. Bagi sebagian besar siswa, yang diperlukan mereka ialah penguasaan bahasa serta keterampilan berbahasa baik lisan maupun tulisan. Tujuan itu hanya dapat dicapai dengan latihan yang terus menerus (Slamet, 2014: 28). Hal ini berkaitan dengan beberapa syarat yang menurut Morsey (dalam Wibowo, 2001) dibutuhkan seseorang untuk menyusun dan mengutarakan pikirannya dengan jelas, yaitu pikiran, organisasi, pemakaian kata-kata, dan struktur kalimat. Berkaitan dengan kompleksnya syarat yang dimiliki seseorang 
untuk menyusun pikiran dan mengutarakannya dengan jelas dalam bentuk tulisan, penambahan alokasi waktu untuk aktivitas menulis di kelas diperlukan dalam rangka latihan dan praktik menulis yang banyak dan teratur.

\section{Kesalahan Ejaan adalah Kesalahan yang Dominan}

Berdasarkan hasil penelitian di atas, kesalahan ejaan adalah kesalahan yang paling banyak ditemukan pada karangan eksposisi siswa daripada kesalahan penyusunan kalimat dan kesalahan pemilihan kata. Penelitian Turistiani (2013), Nur Hady Eko Setiawan (2014), Yulianto Adhi Dharma Loka (2014), dan Umi Faizah (2014) juga menyimpulkan bahwa kesalahan ejaan adalah kesalahan dengan persentase tertinggi dibandingkan aspek kesalahan berbahasa yang lain.

Analisis kesalahan penggunaan ejaan, dalam penelitian ini, didasarkan pada Pedoman Umum Ejaan Bahasa Indonesia Edisi Keempat yang diterbitkan oleh Badan Pengembangan dan Pembinaan Bahasa Kementerian Pendidikan dan Kebudayaan tahun 2016, terutama pada bab 1 pemakaian huruf, bab 2 penulisan kata, dan bab 3 pemakaian tanda baca. PUEBI Edisi Keempat merupakan buku rujukan yang dapat dijadikan pedoman dan acuan berbagai kalangan pengguna bahasa Indonesia (termasuk siswa), terutama dalam pemakaian bahasa tulis, secara baik dan benar. Oleh karena itu, data temuan berupa kesalahan berbahasa bidang ejaan pada karangan eksposisi siswa dianalisis berdasarkan pedoman dan acuan penulisan dalam PUEBI tersebut. Menurut Turistiani (2013), kesalahan penggunaan ejaan merupakan bentuk kesalahan yang serius dan perlu mendapat perhatian. Kesalahan penggunaan ejaan termasuk kesalahan intrabahasa. Kesalahan tersebut disebabkan oleh ketidaktahuan mahasiswa (dalam hal ini siswa) pada kaidah dan penerapan kaidah yang tidak sempurna.

\section{Kecenderungan Siswa Menomorduakan Tata Tulis dibandingkan Ide Karangan}

Penyebab kesalahan berbahasa yang dilakukan siswa saat menulis karangan eksposisi adalah kecenderung mereka untuk menomorduakan tata tulis dibandingkan ide karangan. Kondisi ini turut didukung oleh alokasi waktu kegiatan menulis yang terbatas dan ketentuan guru tentang jumlah kata minimal dalam sebuah karangan yang harus dipenuhi siswa. Oleh karena itu, siswa lebih fokus pada ide yang akan dituliskan dan cenderung mengesampingkan kaidah penulisan yang baik dan benar.

Sukyadi (dalam penelitian berjudul Kesalahan Sintaksis dalam Tulisan Pebelajar Bahasa Inggris) berpendapat bahwa pada kegiatan menulis yang melibatkan proses berpikir yang lebih abstrak dan kompleks, seperti pada penyusunan esai, saat penulis lebih memusatkan perhatian pada makna daripada bentuk, diduga perhatian utama penulis bukan tertuju pada struktur sintaktis tetapi lebih pada isi, organisasi, atau aspek lainnya. Pendapat ini menjelaskan adanya kecenderungan siswa untuk menomorduakan tata tulis dibandingkan ide karangan saat aktivitas mengarang. Kecenderungan ini merupakan faktor penyebab kesalahan berbahasa pada karangan eksposisi siswa.

\section{Aktivitas 'Saling baca Karangan antarsiswa' \\ Upaya yang dapat ditempuh siswa} untuk meminimalisasi kesalahan berbahasa pada karangan eksposisinya adalah menerapkan aktivitas saling-baca karangan antar-siswa dalam rangka revisi sebelum dikumpulkan pada guru. Berkaitan dengan penerapan aktivitas saling baca karangan antarsiswa sebagai upaya meminimalkan kesalahan berbahasa pada karangan siswa, 
Sukyadi (dalam penelitian berjudul

Kesalahan Sintaksis dalam Tulisan

Pebelajar Bahasa Inggris) menyebutnya dengan teknik menulis kolaboratif. Dengan teknik ini, responden (siswa) diminta menulis sebuah paragraf, tetapi sebelum dianggap selesai mereka meminta salah seorang temannya mengoreksi tulisan tersebut. Hasilnya, kesalahan sintaktis berkurang secara signifikan. Selain itu, teknik menulis kolaboratif juga dapat meningkatkan kesadaran linguistik kedua belah pihak, pemilik naskah atau pembacanya karena masing-masing pihak disadarkan atas aturan gramatikal yang mereka tidak sadari ketika proses menulis dilakukan. Menurut Sukyadi, pengoreksian tulisan oleh teman sebaya sudah sepantasnya dikembangkan menjadi sebuah kegiatan yang tidak terpisahkan dari kegiatan menulis sekaligus mengatasi keluhan tentang kurangnya waktu yang tersedia untuk guru memeriksa tulisan pebelajar satu per satu.

Selain itu, Sudiara (dalam penelitian berjudul Upaya Meminimalkan Kesalahan Bahasa Tulis Siswa melalui Aktivitas Menganalisis Kesalahan dalam Pembelajaran Menulis) menyimpulkan bahwa aktivitas menganalisis kesalahan dalam pembelajaran menulis dapat meminimalkan kesalahan bahasa tulis siswa berkat meningkatnya penguasaan mereka terhadap aspek-aspek kebahasaan, dan dapat meningkatkan kegairahan belajar siswa dalam bidang menulis. Selain itu, pengoreksian draf awal tulisan siswa secara silang sambil berdiskusi antar teman ternyata lebih disenangi oleh siswa dibandingkan dengan pengoreksian tanpa diskusi. Hal ini berkaitan dengan pemberian balikan dari guru atau siswa lain selama diskusi dapat menyebabkan seorang siswa tidak hanya menemukan ide-ide baru. Selain itu, kalimatkalimat dan kata-kata yang baru dapat dijadikan bahan untuk memperbaiki draf awal karangannya sendiri.

\section{SIMPULAN}

Simpulan penelitian ini adalah sebagai berikut. Pertama, kesalahan bahasa dalam karangan eksposisi siswa dibagi menjadi tiga kesalahan: kesalahan kalimat, kesalahan diksi, dan kesalahan ejaan. Kedua, kesalahan ejaan adalah kesalahan yang paling banyak ditemukan pada karangan eksposisi siswa dengan frekuensi tertinggi pada penggunaan tanda koma. Ketiga, faktor penyebab kesalahan bahasa pada karangan eksposisi siswa, antara lain: minimnya pengetahuan siswa tentang kaidah penulisan, minimnya motivasi membaca siswa, kecenderungan siswa menomorduakan tata tulis dibandingkan ide karangan, kebisaan siswa untuk tidak merevisi karangan sebelum dikumpulkan, suasana kelas yang tidak kondusif, dan tuntutan kompetensi menulis yang sebatas benar secara struktur teks. Keempat, upaya yang dilakukan untuk meminimalisasi kesalahan berbahasa, antara lain guru segera mengklarifikasi kesalahan berbahasa siswa yang ditemukan dalam pembelajaran, antarsiswa melakukan aktivitas saling-baca karangan sebelum dikumpulkan kepada guru, dan penambahan alokasi waktu untuk aktivitas menulis di kelas.

Aktivitas menulis akan menjadi aktivitas yang menyenangkan saat siswa memiliki pengetahuan yang cukup mengenai ide tulisan dan cara menuangkannya dalam bentuk tulisan yang baik dan benar. Kesulitan aktivitas menulis, seperti mentok ide dan minimnya pengetahuan mengenai kaidah penulisan yang baik dan benar, dapat diatasi siswa dengan membiasakan diri aktif membaca. Motivasi membaca yang tinggi akan membantu siswa untuk meminimalisasi kesalahan berbahasa dalam aktivitas menulisnya. Selain aktif membaca, siswa juga dapat aktif menanyakan kesulitan yang ditemui selama menulis kepada guru.

Berkaitan dengan kecenderungan siswa untuk menomorduakan tata tulis 
dibandingkan ide karangan selama kegiatan mengarang, guru perlu menerapkan teknik saling-koreksi karangan antarsiswa dan diskusi sebelum karangan dikumpulkan kepada guru. Pemberian balikan dari guru atau siswa lain selama diskusi dapat menyebabkan seorang siswa tidak hanya menemukan ide-ide baru, tetapi juga kalimat-kalimat dan kata-kata baru yang dapat dijadikan bahan guna memperbaiki karangannya sendiri.

Berkaitan dengan aktivitas menulis dalam kurikulum 2013 yang bukan suatu kegiatan mandiri, alokasi waktu untuk aktivitas menulis perlu ditambah. Hal ini sebagai upaya pemberian akses yang lebih besar bagi siswa untuk menambah pengetahuan dan keterampilannya mengenai kaidah penulisan bahasa Indonesia yang baik dan benar.

\section{REFERENSI}

Dalman. (2015). Penulisan Populer. Jakarta: Rajawali Pers.

Krippendorff, Klaus. (2004). Content Analysis An Introduction to Its Methodology Second Edition. London: Sage Publications.

Marahimin, Ismail. (1999). Menulis secara Populer. Jakarta: Dunia Pustaka Jaya.

Slamet, St. Y. (2014). Problematika Berbahasa Indonesia dan Pembelajarannya Edisi 2. Yogyakarta: Graha Ilmu.

Sudiara, I Nyoman Seloka. (2002). Upaya Meminimalkan Kesalahan Bahasa Tulis Siswa melalui Aktivitas Menganalisis Kesalahan dalam Pembelajaran Menulis. Diperoleh tanggal 17 Oktober 2017, dari http://lemlit.undiksha.ac.id/images/im g_item/619.doc

Sukyadi, Didi. (2005). Kesalahan Sintaksis dalam Tulisan Pebelajar Bahasa Inggris dan Upaya Perbaikannya
Materi pragmatik, seperti menulis lamaran pekerjaan, wawancara, surat, dll, perlu dimasukkan ke kurikulum Bahasa Indonesia 2013. Dengan materi tersebut, siswa diajak untuk benar-benar menggunakan bahasa sesuai kebutuhan sehari-hari. Selain itu, materi tersebut sangat efektif untuk membenahi kebahasaan pada tulisan siswa.

Data temuan dalam penelitian ini dapat dijadikan referensi bagi penelitian sejenis maupun penelitian pengembangan yang berkaitan dengan upaya yang dapat dilakukan untuk meminimalisasi kesalahan berbahasa pada karangan siswa. Hasil temuan ini sebaiknya bisa dimanfaatkan dan ditindaklanjuti guru untuk diterapkan dalam pembelajaran menulis.

melalui Teknik Menulis Kolaboratif. Jurnal Ilmu Pendidikan Juni 2005, 12 (2). Dari http://journal.um.ac.id/ index.php/jip/article/download/74/140 9

Sutopo, H.B. (2002). Metodologi Penelitian Kualitatif Dasar Teori dan Terapannya dalam Penelitian. Surakarta: UNS Press Surakarta

Tarigan, Hendry Guntur dan Djago Tarigan. (1990). Pengajaran Analisis Kesalahan Berbahasa. Bandung: Angkasa.

The Liang Gie. (1995). Pengantar Dunia Karang-mengarang. $\quad$ Yogyakarta: Liberty Yogyakarta.

Tim Pengembang Pedoman Bahasa Indonesia. (2016). Pedoman Umum Ejaan Bahasa Indonesia Edisi Keempat. Jakarta: Badan Pengembangan dan Pembinaan Bahasa Kementerian Pendidikan dan Kebudayaan. 
Turistiani, Trinil Dwi. (2013). Fitur Kesalahan Penggunaan Ejaan Yang Disempurnakan dalam Makalah Mahasiswa. Paramasastra Jurnal Ilmiah Bahasa Sastra dan Pembelajarannya September2013,1(1).

Wibowo, Wahyu. (2001). Manajemen Bahasa Pengorganisasian Karangan Pragmatik dalam Bahasa Indonesia untuk Mahasiswa dan Praktisi Bisnis. Jakarta: Gramedia Pustaka Utama. 